\title{
MONETARY POLICY BEFORE AND AFTER THE FINANCIAL CRISIS. EVIDENCE FROM INFLATION TARGETING COUNTRIES IN CENTRAL AND EASTERN EUROPE
}

\author{
Ioana Pleșcău \\ PhD Student \\ Faculty of Economics and Business Administration \\ Alexandru Ioan Cuza University of Iasi \\ ioana.plescau@yahoo.com
}

\begin{abstract}
The aim of our study is to review the monetary framework and instruments adopted by the inflation-targeting countries in Central and Eastern Europe, from 2005-ownwards. We employ a qualitative approach and develop a comparative analysis of the changes that occurred in the conduct of monetary policy after the 2008 financial crisis. The results highlight that the central banks in our sample have adjusted their policy in order to counteract the effects of the financial crisis and adopt different instruments to fulfill this aim. The contribution of our study is twofold. First, we offer a review of the literature regarding the adjustments in the monetary policy after the crisis and their effectiveness. Second, we make a comparative analysis between countries with respect to the path of monetary policy from conventional to unconventional and assess the (potential) way back.
\end{abstract}

\section{Keywords}

monetary policy; inflation targeting; unconventional monetary policy; monetary instruments

\section{JEL Classification}

E42; E43; E51; E52; E58

\section{Introduction}

In the aftermath of the recent financial crisis, central banks around the world have changed their view regarding how to conduct the monetary policy. We can observe a development and a continuous evolution of the operational framework of monetary policy, with the aim of counteracting the effects of the 2008 financial crisis and, why not, with the aim of preventing the occurrence of a new, even stronger, financial crisis. In this study we look at the monetary policy implemented by the inflation-targeting countries in Central and Eastern Europe before 2008 and we follow the path of the monetary policy instruments after the outbreak of the financial crisis. We choose to conduct this monetary analysis on inflation targeting countries for comparability reasons. Inflation targeting is a monetary regime under which a central bank establishes a nominal target for inflation (Schmidt-Hebbel and Carrasco, 2016; MackiewiczLyziak, 2016). Also, the monetary authority makes every effort to use the most appropriate instruments and strategy in order to achieve that target. In this monetary framework, a central bank takes into account the projections for the economy and, especially, for the inflation rate when deciding the path of interest rates. In this sense, inflation targeting is a forward-looking regime (Mackiewicz-Lyziak, 2016). Moreover, Schmidt-Hebbel and Carrasco (2016) argue that inflation targeting regime is characterized by a high degree of policy independence, transparency and accountability. Furthermore, inflation targeting regime means that the central banks has 
the price stability as a primary objective. However and especially after the 2008 financial crisis, many central banks take into account the financial stability objective. First, we analyze the monetary strategy of the countries under review and its path from conventional to unconventional. Second, we offer a comparative analysis of the six countries in our panel.

Our sample consists of the inflation targeting countries in Central and Eastern Europe, in a chronological order of the year of adopting this regime: Czech Republic, Poland, Hungary, Romania, Serbia and Albania. We do not study the case of Ukraine, since it has entered in a first phase in the process of adopting inflation targeting regime only recently, in 2016.

Our research focus is to review the monetary instruments that were used by the monetary authorities of the countries included in our analysis ${ }^{1}$.

\title{
Monetary policy: the path from conventional to unconventional
}

\begin{abstract}
Albania (inflation targeting regime since 2009)
Albania National Bank is the monetary authority in Albania. It has also the role of macroprudential supervisor. Albania has started using inflation targeting since 2009.

In the period of our analysis, the Bank of Albania had the same inflation target, with the level of $3 \%$, allowed to fluctuate within a band of $1 \%$. The changes that occurred in the operational framework of the Albanian monetary policy is related to the steering of interest rate money market since 2009 as an operational objective. Bank of Albania uses the rate applied in the one-week repurchase and reverse-repo agreements as the main instrument of monetary policy, together with the other three categories of instruments: open-market operations, standing facilities and required reserve rate. Moreover, starting with the Monetary Policy Document from 2012, the Bank of Albania use the liquidity-provisioning operations (the Lombard loan) as an additional instrument of monetary policy to sustain the banking system. Also, in the Monetary Policy Document for the period 2014-ownwards, Bank of Albania mentions the forward guidance as an unconventional instrument to complement the traditional ones used until now. The Bank of Albania pursuit an expansionary monetary policy to counteract the effects of the financial crisis. In 2008 the key policy rate in Albania was $6.25 \%$ and it was decreased many times until it has reached the current $1.25 \%$ level (March 2017) after the $0.25 \%$ decrease decided in May 2016. Also, as Bartlett and Monastiriotis (2010) argue, Bank of Albania used liquidity injections in order to sustain the banking system and the whole economy.
\end{abstract}

\section{Czech Republic (inflation targeting regime since 1998)}

Czech Republic has started to use the inflation targeting regime since 1998. It was the first country in Central and Eastern Europe that have adopted this monetary regime. Czech National Bank uses a tolerance band of $1 \%$ and its inflation target is $2 \%$, as it was announced in March 2007, with de-facto effect starting from January 2010. Historically, the target level of inflation has decreased from 6.5\% (1998). The primary instrument of monetary policy is the level of interest rate. Since the outbreak of the 2008 financial crisis, central bank in Czech Republic used its conventional instrument to support the economy. In this sense, it has lowered gradually the key interest rate, until it has reached the zero-lower bound in autumn 2012 (CNB, 2013). Also, Czech National Bank (CNB) uses the following additional instruments: open market

\footnotetext{
${ }^{1}$ We use the websites of the national banks as a source for information regarding the monetary policy framewwork
} 
operations, automatic facilities, liquidity-providing repo operations, minimum reserves, foreign-exchange interventions. Following the financial crisis, CNB have started to use some extraordinary liquidity-providing operations. In autumn 2008, the central bank adopted the 2-week and 3-month maturities for the repo operations, as unconventional measures. The 3-month maturity was abandoned in January 2011, but the CNB continues to use the 2-week maturity for the liquidity-providing repo operations.

Another instrument that was used for unconventional purposes in times of crisis is represented by the foreign-exchange interventions. Although they are not the standard instrument in the inflation targeting framework, they can be used in situations when interest rate hits the zero-lower bound. Since November 2013, Czech National Bank have engaged to use foreign-exchange interventions in order to weaken the Czech Koruna, as an alternative instrument for expansionary monetary policy. The nonstandard measure is known as the exchange rate commitment and it is a one-sided instrument in which CNB only looks after the weakening and not the appreciation of the koruna. This commitment means that CNB sells koruna and buys foreign currency in order to keep the exchange rate close to CZK 27/EUR. In a Statement of the Czech National Bank Board for the press after the monetary policy meeting in February 2017, the central bank mentions that it will continue to use the exchange rate as an unconventional monetary instrument which will be, probably, exited from starting with mid-2017. Indeed, in an extraordinary meeting that has taken place in April 2017, CNB has announced that it will stop using the exchange rate commitment and return to the conventional monetary framework which has the interest rate as main instrument and the free-floating exchange rate regime.

\section{Hungary (inflation targeting regime since 2001)}

The Magyar Nemzeti Bank (MNB) is the monetary authority in Hungary. The MNB has adopted the inflation targeting regime in 2001. Since August 2005, the MNB have established a nominal target of 3\% and, starting with March 2015, it has also added a fluctuation band of $1 \%$ to the established target. The main monetary policy instrument used by the MNB is the 3-month deposit, which is also the key policy rate. Also, the MNB use overnight standing facilities and minimum reserve requirements as additional monetary instruments. Moreover, in the light of the financial crisis, the MNB have decided to publish its forecasts regarding the determinants that affect the liquidity needs of the banks. Since this decisions was taken in September 2010, we can say that liquidity forecast may be seen as an unconventional monetary instrument used by the MNB to support the banking system. Furthermore, the MNB have continuously revised its monetary policy instruments ${ }^{2}$ in its efforts to counteract the negative effects of the financial crisis on the banking system and support its liquidity level.

In 2008 the MNB have introduced two lending facilities and loan tenders once a week. Also, in October 2008, the MNB adopted an agreement with the European Central Bank regarding the introduction of an overnight foreign-exchange swap to provide euro liquidity. Moreover, in March 2009, the agreement was extended through the introduction of 3-month foreign exchange swap tenders. This last instrument was abandoned in November 2016. In 2012 the Magyar Nemzeti Bank start using a 2-year variable rate loan tender with the interest rate indexed to the key policy rate. These loan tenders were discontinued in April 2013. In addition to this, the MNB used euro sale tenders from October 2014 until January 2015 and Swiss franc sale tenders from August to September 2015. In 2016 the MNB introduced a 1-week deposit instruments and a foreign exchange swap with the following maturities: 1-week, 1-month and 3-month.

\footnotetext{
2 The information regarding the monetary policy instruments used by the Magyar Nemzeti Bank is retrieved from the MNB website.
} 
Another unconventional measure used by the Magyar Nemzeti Bank is the Selffinancing Programme adopted in April 2014. Together with this programme, the MNB revised its instruments and introduced, in June 2014, an interest rate swap and two potential instruments: a 3-year collateralized forint loan facility and an asset swap facility. In addition to this programme, the MNB introduced a Market-Based Lending Scheme in January 2016 in order to sustain the bank lending to SMEs and, furthermore, to stinulate the whole macroeconomy. This Lending Scheme translated into a lending interest rate swap facility and a preferential deposit facility.

\section{Poland (inflation targeting regime since 1998)}

Narodowy Bank Polski (NBP) is the central bank and the monetary authority in Poland. It has adopted the inflation targeting regime in 1998 and it has established a nominal target of $2.5 \%$ for the inflation rate, allowed to fluctuate within a tolerance band of $\pm 1 \%$. Within this monetary framework, the basic instrument used by the NBP is the official interest rate. Also, it uses the other monetary instruments as: open market operations, credit-deposit operations and reserve requirement rate. Until the 2008 financial crisis, those were mainly the instruments that the NBP use to influence the interest rates and, further on, to preserve price stability and foster economic growth. However, in 2008 the effects of the crisis were felt in Poland, also. To overcome these negative effects, the NBP introduces some additional instruments in 2008. In October 2008, the Narodowy Bank Polski adopted the "Confidence Pact" (NBP, 2009) and new monetary instruments related to this Pact: repo operations to support the liquidity of the banking system, currency swap transactions and fine-tuning operations. Regarding these fine-tuning operations, the NBP introduced the short-term NBP bills with 3-day and 2-day maturities. In addition to these measures, the NBP supplemented the basic open market operations and introduced the standing facilities on the initiative of the banks. The measures introduces under the "Confidence Pact" have continued in 2009 also. Additionally, in 2009 the NBP decided to use structural operations to change the long-term structure of liquidity in the banking sector. In concrete terms, the NBP introduced the possibility of early redemption of the NBP bonds. In 2010, the NBP use the repo operations, but the foreign exchange swap facility was no longer accessed. All in all, Narodowy Bank Polski use the repo operations in 2008, 2009 and 2010 and the foreign exchange swaps in 2008 and 2009 in order to sustain the liquidity of the banking system and to offer support to the economy to overcome the negative effect of the financial crisis. Important to mention is the fact that NBP have also constantly lowered the interest rate to reflect the expansionary stance of the monetary policy.

\section{Romania (inflation targeting regime since 2005)}

The National Bank of Romania (NBR) is the monetary authority in Romania. It introduced the inflation targeting regime in 2005 and since 2013 it has followed an inflation target of $2.5 \%$ together with a fluctuation band of $1 \%$ in either direction. To achieve this target, the NBR uses the monetary policy as a primary instrument, together with the other three conventional instruments: open market operations, standing facilities and reserve requirements. In the wake of the crisis, NBR has also decreased the level of interest rate. However, in comparison with the other countries, NBR use a slow rate of reduction for the interest rate. Also, NBR use the interventions on the foreign-exchange market as an alternative instrument to overcome the effects of the crisis. Moreover, to avoid a deep depreciation of the national currency, NBR sold foreign currencies and made every effort to preserve a relative high interest rate (Croitoru, 2014). As Criste (2014) argue, after the financial crisis, NBR focused more on macroprudential measures than on unconventional monetary instruments, as the other countries in our review. 


\title{
Serbia (inflation targeting regime since 2009)
}

National Bank of Serbia (NBS) conduct the monetary policy in Serbia and, since 2009, it engages in preserving the price stability, following an inflation target of $3 \%$ with a fluctuation band of $1.5 \%$ in either direction. Besides using the key policy rate as the main monetary instrument, the NBS also employs open market operations, required reserves, standing facilities and interventions in the foreign exchange market. In addition to these standard instruments, NBS offered in 2009 and 2010 short-term liquidity loans against collateral of securities, in order to support the banking system. Since 2011, they are used for managing the bank liquidity.

\section{Data and analysis}

The aim of our paper is to analyze the influence of low interest rates (as an unconventional monetary instrument to overcome the crisis) on the economic growth and inflation rate. We conduct a comparative analysis between the inflation targeting countries in Central and Eastern Europe in order to highlight the differences in terms of interest rates and the effects on the macro-economy.
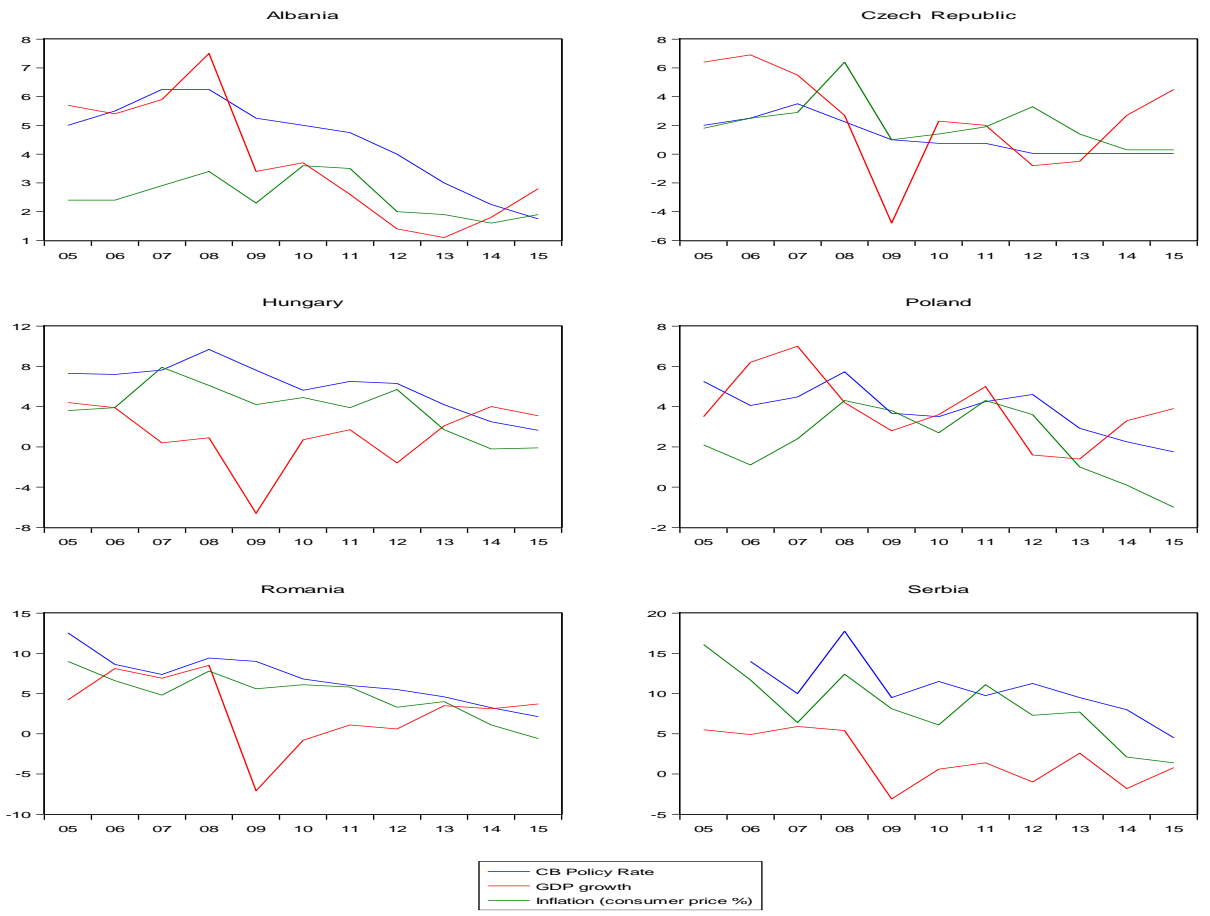

Figure 1: The evolution of CB policy rate, economic growth and inflation in the IT countries from CEE - period 2005-2015

\author{
Source: own computations
}

Our sample consists of the inflation targeting countries from CEE region. We analyze information regarding the central bank policy rate, the economic growth (GDP growth) and the inflation rate - CPI (Consumer Price Index). We use the websites of each central bank to obtain data regarding the monetary instruments and the level of interest rates. Also, we use the World Bank as a datasource for GDP growth and CPI -inflation. 
Figure 1 shows the evolution of the main macro-indicators from the inflation targeting (IT) countries in Central and Eastern Europe, for each individual cross-section. The dynamics of the central bank policy rate (CB policy rate) shows the expansionary stance of the monetary policy that has been employed after the financial crisis. However, out of the six analyzed countries, only Czech Republic have reached the zero-lower bound (with a value of $0.05 \%$ established since 2012 ownwards). This was the main reason why Czech National Bank has implemented the exchange rate commitment as an alternative instrument to support the banking system and encourage the economy. Moreover, there is an obvious tendency of very low interest rates observed in the analyzed countries especially after the 2011 euro-crisis. Regarding the economic growth, there was a drop in the GDP growth rate after the financial crisis that has shown its negative effects especially in 2009. In spite of 2011 debt crisis, the analyzed countries registered an economic recovery in 2010-2011 period. However, Figure 1 supports the low inflation paradox, showing low levels of the CPI - inflation rate for period after the financial crisis.
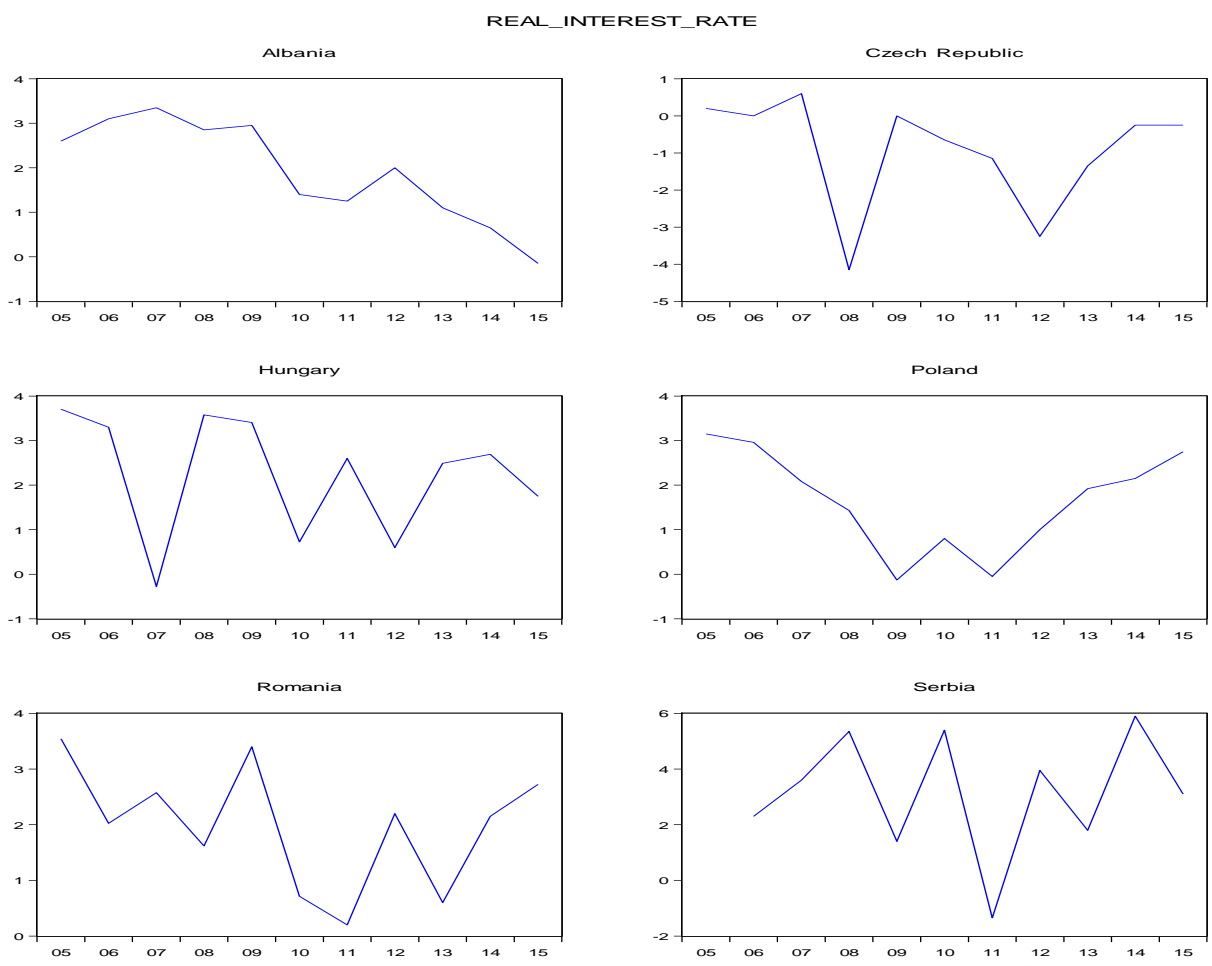

Figure 2: The evolution of real interest rate in IT countries from CEE period 2005-2015

Source: own computations

Regarding the impact of the unconventional, non-standard measures that were employed by the central banks, we can notice that the economic recovery highlighted in Figure 1 supports the fact that credit easing measures have encouraged the GDP growth, although they have little effect on raising the inflation rate. Our analysis supports the findings obtained in previous studies regarding the effects of unconventional monetary policy (Baumeister and Benati, 2010; Chodorow-Reich, 2014; Rogers et al., 2014; Engen et al., 2015).

Another important aspect that is to be analyzed in the context of low interest rates is the evolution of real interest rates, which basically show the relation between nominal 
interest rates and inflation. Figure 2 shows that Czech Republic has negative real interest rates and this highlight the zero-lower bound situation that this country reached after the 2008 financial crisis. Romania is the only country out of the six in our sample that did not registered negative values for the real interest rate during the period 20052015. Moreover, Albania is the only country that has an obvious trend of decreasing real interest rates.

\section{Conclusion}

Analyzing the evolution of the macro indicators synthesized in Figures 1 and 2, we can observe that the non-traditional monetary measures that were employed by the inflation targeting countries in Central and Eastern Europe managed to avoid a deeper economic crisis, after the financial events in 2008. However, there is a high interconnection between the banking systems in CEE region, because most of the existing banks are foreign-owned and this was one of the transmitting channels for the effects of the financial crisis. Even if the analyzed countries have not implemented strictly-speaking unconventional monetary instruments (as FED and ECB have done using the Quantitative Easing in case of United States and the Eurozone), the central banks have expanded their monetary tools and developed instruments with the aim of easing the credit conditions of the commercial banks, to encourage the crediting activity and to support the liquidity of the banking system. Also, the measures adopted after the 2008 financial crisis managed to restore the economic growth and avoided the collapse of the banking system.

\section{References}

Bartlett, W., Monastiriotis, V. (2010), South Eastern Europe after the Crisis: a new dawn or back to business as usual? London School of Economics and Political Science, Research on South Eastern Europe.

Baumeister, C., Benati, L. (n.d.), Unconventional Monetary Policy and the Great Recession: Estimating the Macroeconomic Effects of a Spread Compression at the Zero Lower Bound. International Journal of Central Banking, 9, 165212.

Chodorow-Reich, G. (2014), Effects of unconventional monetary policy on financial institutions. Brookings Papers on Economic Activity, Spring 2014.

CNB. (2013), 7th Situation Report on Economic and Monetary Developments. Press conference of the CNB Bank Board, 7 November 2013.

Criste, A. (2014), Monetary policy adjustments at the global fianancial crisis constraints. Hyperion Economic Journal, 4(2), 3-11.

Croitoru, L. (2014), Politica ratei dobanzii și povara creditelor. retrieved from http://www.bnr.ro/Puncte-de-vedere-4011.aspx.

Engen, E., Laubach, T., \& Reifschneider, D. (2015), The macroeconomic effects of the Federal Reserve's unconventional monetary policies. Board of Governors of the Federal Reserve System. Finance and Economic Discussion Series 2015005 .

Mackiewicz-Lyziak, J. (2016), Active and Passive Monetary Policy in CEE Countries with Inflation Targeting: The case of the Czech Republic, Hungary and Poland. Eastern European Economics, 54(2), 133-152.

Rogers, H., Scotti, C. (2014), Evaluating Asset-Market Effects of Unconventional Monetary Policy: A Cross-Country Comparison. Board of Governors of the Federal Reserve System . International Finance Discussion Paper No. 1101. 
Schmidt-Hebel, K., Carrasco, M. (2016), The Past and Future of Inflation Targeting. Retrieved from https://www.bcb.gov.br/pec/depep/Seminarios/2016_XVIIISemAnualMetasI nfBCB/SMETASXVIII-\%20Klaus\%20Schmidt.pdf 